\title{
IN VITRO CYTOTOXICITY ACTIVITY OF METHANOLIC LEAF AND FRUIT EXTRACT OF ZANTHOXYLUM OVALIFOLIUM WIGHT AGAINST DALTON'S LYMPHOMA ASCITES AND EHRLICH ASCITES CARCINOMA CANCER CELL LINES
}

\author{
PAVANI P*, RAJA NAIKA \\ Department of Applied Botany, Kuvempu University, Shimoga, Karnataka, India. Email: pavani.raju10@gmail.com \\ Received: 18 June 2019, Revised and Accepted: 16 September 2019
}

\begin{abstract}
Objectives: The objective of the present study, the methanolic leaf and fruit extraction of Zanthoxylum ovalifolium, was examined for in vitro cytotoxicity using trypan blue dye exclusion technique.

Methodology: In vitro cytotoxicity activity of methanolic leaf and fruit extracts of Z. ovalifolium. Against Dalton's lymphoma ascites (DLA) and Ehrlich ascites carcinoma (EAC) cell lines evaluated using trypan blue exclusion method. Non-viable cell absorbs blue color of trypan blue while viable cell does not absorb the dye. The percentage of total number of viable and non-viable cells is calculated using $\%$ viability=(live cell count/total cell count) $\times 100$

Results: Cytotoxicity activity of methanolic leaf and fruit extract against chosen tumor cell line at different concentrations of $10,20,50,100$, and $200 \mu \mathrm{g} / \mathrm{ml}$, respectively. The result confirmed that the fruit extract at 200 showed less toxic effect against DLA and EAC cell line showed $72 \%$ and $75 \%$ of inhibition growth of cell line and the most potent $80 \%$ and $82 \%$ of cell death were found in leaf extract against the chosen tumor cell line. The present study indicates that both leaf and fruit extract of $Z$. ovalifolium were appreciable antitumor activity against DLA and EAC cell lines may be due to the presence of phytochemicals such as flavonoids and alkaloids present in the plant.
\end{abstract}

Conclusion: Zanthoxylum ovalifolium wight fruit and leaf methanolic extracts showed satisfying result of cytotoxicity activity against DLA and EAC cell line. Hence, Z.ovalifolium could be suggested as an important source of anticancer agent for pharmacological industries.

Keywords: Zanthoxylum ovalifolium weight, Phytochemical analysis, Anticancer activity, Ehrlich ascites carcinoma, Dalton's lymphoma ascites cell lines.

(C) 2019 The Authors. Published by Innovare Academic Sciences Pvt Ltd. This is an open access article under the CC BY license (http://creativecommons. org/licenses/by/4. 0/) DOI: http://dx.doi.org/10.22159/ajpcr.2019.v12i11.34607

\section{INTRODUCTION}

Cancer is the second major foremost cause of human death after cardiovascular diseases [1,2]. Cancer is a disease in which the cell undergoes abnormal and multiple growth of cell in human body with the great power to invade or spread to other parts of the body [3]; there are about 100 types of cancer including breast cancer, skin cancer, lung cancer, colon cancer, and lymphoma. With changing or sedentary lifestyle including food practice and exposure to different types of chemicals and radiation, as also due to availability of curative treatment for many infectious diseases, cancer is surpassing other illnesses as a principle cause of morbidity and mortality even in developing countries [4]. According to the WHO report, from the past three decades of the $20^{\text {th }}$ century, the world cancer problem was doubled, and it is approximate that between 2000 and 2020, it will be doubled and likely to increase each year [5]. There are different modern ways present to treat cancer such as chemotherapy, surgery, radiation therapy, immunotherapy, targeted therapy, and stem cell therapy, but these treatments are expensive, mutilating, have a narrow margin of safety. Therefore, the present-day research is aimed on considerable scientific and commercial interest in new identification of novel, safe, and low cost with most effective anticancer drug from natural plant source.

Medicinal plants are playing a key role as a source of successful anticancer agents. As per the World Health Organization's report, the early 90s, a very high percentage of the world population depends on plantbased remedy to cover the needs of the primary medical care. Plants have many bioactive compounds with a variety of pharmacological activities; it is significant that $60 \%$ of currently used anticancer agents are derived from natural sources including plants [6]. India is one of the rich biodiversities in the world and is well acknowledged for traditional system of medicine - Ayurveda, Siddha, and Unani. Medical systems are found mentioned even in the ancient Vedas and other scriptures. The Ayurvedic concept appeared and developed between 2500 and 500BC in India [7].

Zanthoxylum ovalifolium belongs to a lemon family (Rutaceae). The plant $Z$. ovalifolium is also called as yellow wood. It is an aromatic plant and erect shrub or small tree growing up to $8 \mathrm{~m}$ tall. An essential oil is obtained from the fruit. In Zanthoxylum genus, it is common to find secondary metabolites such as alkaloids, lignin, coumarins, amides, flavonoids, and triterpenes [8,9]. Many species of Zanthoxylum studied for anticancer activity Zanthoxylum monogynum [10], Zanthoxylum armatum [11], Zanthoxylum alatum [12], Zanthoxylum ailanthoides, Zanthoxylum nitidum, Zanthoxylum pistaciiflorum, and Zanthoxylum simulans [13]. No pharmacological investigation in the perspective of anticancer activity has yet been studied on $Z$. ovalifolium.

Therefore, in the current investigation carried out, a screening of methanolic leaf and fruit extracts of Z $\mathrm{Z}$. ovalifolium was the analysis of preliminary phytochemical and investigated for anticancer activity against Dalton's lymphoma ascites (DLA) and Ehrlich ascites carcinoma (EAC) cell lines.

\section{METHODOLOGY}

Collection of plants

The fresh leaf and fruits of Z. ovalifolium have been collected in and around Sringeri, Agumbe region, Karnataka, India, during June 2017. The plant material was identified using the help of flora (J.S. Gamble). 
Herbarium specimen is preserved in the Department of P.G Studies and Research in Applied Botany, Jnanasahyadri, Kuvempu University. The plant material was dried at room temperature and powdered in a mixer grinder for further analysis.

\section{Cancer cell lines}

Two cancer cell lines, namely, EAC and DLA were obtained under the courtesy of Amala Cancer Research Center, Trissur, India. These cell lines were maintained by weekly intraperitoneal inoculation of 106 cells/per mouse.

\section{Preparation of extraction}

In this study, hexane, ethyl acetate, and methanol solvents were used separately for the preparation of the different extracts of leaf and fruits from $Z$. ovalifolium based on increasing in the polarity of solvents. Extraction of $Z$. ovalifolium carried out using a Soxhlet apparatus. Equal amounts $(100 \mathrm{~g})$ of powdered leaves and fruits were extracted using $(250 \mathrm{ml})$ each solvents hexane, ethyl acetate, and methanol and extraction process continued till the solvent present in the siphon tube turns to colorless then concentrated using rotary evaporator and extracts kept at $4^{\circ} \mathrm{C}$ until used.

$$
\text { Percentage extractive }=\frac{\text { Weight of dried extract }}{\text { Weight of dried plant material }} \times 100
$$

\section{Qualitative phytochemical analysis}

The preliminary phytochemical analysis was carried out using the leaf and fruit extracts of $Z$. ovalifolium. The qualitative phytochemical analysis includes tests for alkaloids, flavonoids, glycosides, saponins, steroids, tannins, phenols, and terpenoids which are the main groups of secondary metabolites.

Following quantitative tests were conducted in the laboratory to confirm the presence and absence of these phytoconstituents.

\section{Test for tannins}

Prepare the solution of plant extract of desired concentration. In a test dry tube, $0.2 \mathrm{ml}$ of selected plant extracts were added to few drops of $1 \% \mathrm{FeCI}_{3}$. A green/blue-black color formed specified presence of tannins.

\section{Test for flavonoids}

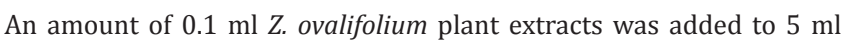
ammonium hydroxide solution and three drops of $\mathrm{H}_{2} \mathrm{SO}_{4}$. The presence of flavonoid confirmed by the formation of a yellow color solution and a white precipitate in a test tube.

\section{Test for saponins}

Formation of foam when $0.1 \mathrm{ml}$ extracts will be shaken vigorously with $3 \mathrm{ml}$ water it shows the presence of saponins.

\section{Test for steroids}

$2 \mathrm{ml}$ of extract was added with $2 \mathrm{ml}$ of con. $\mathrm{H}_{2} \mathrm{SO}_{4}$ and production of wine red color in extract indicates the presence of steroids.

\section{Test for terpenoids}

Golden yellow layer at the interface appears in a test tube with addition of $2 \mathrm{ml}$ of con. $\mathrm{H}_{2} \mathrm{SO}_{4}$ and $2 \mathrm{ml}$ of chloroform to the extract was carefully added to form a layer indicates the presence of tannin.

\section{Test for alkaloids}

Extract was digested with $2 \mathrm{~N} \mathrm{HCL}$ and makes it into two equal portions. One portion was treated with Mayer's reagent (potassium mercuric iodide) and the second portion was treated with Wagner's reagent (potassium iodide). Cream color precipitate and reddish-brown precipitate indicate the presence of alkaloids.

\section{Test for phenol}

Extract was mixed with 0.1 of ferric chloride. Black or greenish-graycolored precipitate indicates the presence of phenols.

\section{Test for glycosides}

Keller-Killiani test was performance to evaluate the presence or absence of glycosides; plant extracts were added with glacial acetic acid and boiled for a minute and cooled. Into this solution, two drops of ferric chloride were added which was transferred to another test tube contains con. $\mathrm{H}_{2} \mathrm{SO}_{4}$ produce a formation of reddish-brown ring at the junction of two layers which indicates the presence of glycosides.

\section{In vitro cytotoxicity assay}

Preparation of cell suspension

Peritoneal fluid $1 \mathrm{ml}$ was withdrawn from DLA/EAC cell line bearing mice. This fluid was diluted with $9 \mathrm{ml}$ of phosphate buffer saline (PBS) and mixed well. Then, it was centrifuged at $2000 \mathrm{rpm}$ for $10 \mathrm{~min}$. Supernatant was removed and settled cells were again resuspended with $9 \mathrm{ml}$ of PBS. This cell suspension was used for further procedure.

\section{Trypan blue dye exclusion test}

Cytotoxicity of fruit and leaves of Z. ovalifolium extracts was assessed using trypan blue exclusion method on DLA and EAC cell lines [14,15]. Trypan blue dye method has the capacity to penetrate into the dead cells and give it blue color. This method gives an exact number of viable and non-viable cells.

The tumor cells aspirated from the peritoneal cavity of tumor-bearing mice were washed 2-3 times with PBS or normal saline. Cell viability was confirmed by trypan blue exclusion method. Viable cell suspension $\left(1 \times 10^{6}\right.$ cells in $\left.0.1 \mathrm{ml}\right)$ was added to tubes containing five different concentrations $(10,20,50,100$, and $200 \mu \mathrm{g} / \mathrm{ml})$ of the drug extracts of $Z$. ovalifolium and the volume was prepared up to $1 \mathrm{ml}$ using PBS. Control tube contained only cell suspension; these assay mixtures were incubated for $3 \mathrm{~h}$ at $37^{\circ} \mathrm{C}$. Further. $0.1 \mathrm{ml}$ of $1 \%$ trypan blue was mixed with the cell suspension and kept for 2-3 min and loaded on a hemocytometer. Non-viable cells take up the blue color of trypan blue while viable cells do not take up the dye. The number of stained and unstained cells was counted separately.

Percentage cytotoxicity $=\frac{\text { Number of dead cells }}{\text { Number of live cells }+ \text { Number of dead cells }} \times 100$

\section{RESULTS AND DISCUSSION}

Medicinal plants play an important role as a source of medicine for human health throughout the world [16]. Plants have been used for varies therapeutic, religious, cosmetic, nutritional, and beautification purposes since the earliest days of humankind and humanity of all civilizations and culture are familiar with their usage. Plants have rich herbal properties and have many secondary metabolites such as alkaloids, steroids, flavonoids, and terpenes with various bioactivities such as antioxidant, antianalgesic, and anticancer properties. Hence, due to the presence of pharmacological properties, the plants play a key role in new drug discovery and developments.

The present study qualitative phytochemical analysis of leaves and fruit extract of $Z$. ovalifolium revealed the presence or absence of bioactive components. In this study, phytoconstituents of three different solvent extracts of fruit and leaves, i.e., hexane-ethyl acetate and methanol extract of $Z$. ovalifolium show the presence of bioactive components such as alkaloids, flavonoids, steroids, phenolic, tannins, saponins, and glycosides. The result of the hexane leaf extract shows the presence of flavonoids, phenols, steroids, and glycosides. The ethyl acetate of leaf extract shows the presence of alkaloids, phenols, and steroids. The ethanol leaf extract shows the presence of alkaloids, tannins, glycosides, phenols, flavonoids, steroids, and terpenoids (Table 1). In fruit extracts of hexane show the presence alkaloids, steroids, phenols, and tannins. Ethyl acetate extract of fruit shows the presence of alkaloids, flavonoids, 
Table 1: Preliminary phytochemical analysis of leaf extract of Zanthoxylum ovalifolium

\begin{tabular}{llll}
\hline Compound & $\begin{array}{l}\text { Hexane } \\
\text { extract }\end{array}$ & $\begin{array}{l}\text { Ethyl acetate } \\
\text { extract }\end{array}$ & $\begin{array}{l}\text { Methanol } \\
\text { extract }\end{array}$ \\
\hline Alkaloids & + & - & + \\
Flavonoids & + & + & + \\
Steroids & + & - & + \\
Phenols & - & + & - \\
Tannins & - & + & + \\
Saponins & - & - & - \\
Glycosides & + & - & + \\
\hline
\end{tabular}

Table 2: Preliminary phytochemical analysis of fruit extract of Zanthoxylum ovalifolium

\begin{tabular}{llll}
\hline Compound & $\begin{array}{l}\text { Hexane } \\
\text { extract }\end{array}$ & $\begin{array}{l}\text { Ethyl acetate } \\
\text { extract }\end{array}$ & $\begin{array}{l}\text { Methanol } \\
\text { extract }\end{array}$ \\
\hline Alkaloids & + & + & + \\
Flavonoids & - & + & + \\
Steroids & + & - & + \\
Phenols & + & - & + \\
Tannins & + & - & + \\
Saponins & - & - & - \\
Glycosides & - & + & - \\
\hline
\end{tabular}

Table 3: Comparison of in vitro cytotoxicity of Zanthoxylum ovalifolium leaf and fruit extracts against DLA cell line

\begin{tabular}{llll}
\hline S. No. & $\begin{array}{l}\text { Drug concentration } \\
(\boldsymbol{\mu g} / \mathbf{m l})\end{array}$ & \multicolumn{2}{l}{ Percentage cell death (DLA) } \\
\cline { 3 - 4 } & & $\begin{array}{l}\text { Leaf } \\
\text { extract }(\%)\end{array}$ & $\begin{array}{l}\text { Fruit } \\
\text { extract (\%) }\end{array}$ \\
\hline 1. & 200 & 80 & 72 \\
2. & 100 & 66 & 60 \\
3. & 50 & 32 & 52 \\
4. & 20 & 20 & 25 \\
5. & 10 & 14 & 20 \\
\hline
\end{tabular}

Control tube contains only one dead cell; the sample dissolves in dimethyl sulfoxide. DLA: Dalton's lymphoma ascites

and glycosides and methanolic extract shows the presence of alkaloids, flavonoids, steroids, tannins, and phenolic compounds (Table 2).

The main objective of our research work on the study of in vitro cytotoxicity of methanolic leaf and fruit extract of $Z$. ovalifolium against tumor cell lines DLA and EAC was determined by trypan blue dye exclusion method. The trypan blue exclusion method based on principle that the viable cell possesses intact cell membrane that excludes certain dyes, whereas non-viable cell does not exclude dye. Our result showed both methanolic leaf and fruit extracts exhibit concentration depend on and depletion of the percentage of viability of cancer cells.

The effect cytotoxicity of leaf and fruit extract of $Z$. ovalifolium against DLA cell line is given in Table 3 and Fig. 1 . The result represents the percentage of cytotoxicity of DLA cell line at various concentrations of drug dosage from $10 \mu \mathrm{g} / \mathrm{ml}$ to $200 \mu \mathrm{g} / \mathrm{ml}$. Leaf extract at lower concentration $10 \mu \mathrm{g} / \mathrm{ml}$ shows $14 \%$ inhibition of cytotoxicity on cell line, whereas $20 \%$ of inhibition was observed in fruit extract. Meanwhile, $20 \%$, $32 \%$, and $66 \%$ of DLA cell death were observed at 20,50 , and $100 \mu \mathrm{g} \mathrm{ml}$ concentration of leaf extract. Fruit extract shows $25 \%, 52 \%$, and $60 \%$ of cell death at 20,50 , and $100 \mu \mathrm{g} / \mathrm{ml}$ concentrations. The maximum effect of cytotoxicity on DLA cell observed at $200 \mu \mathrm{g} / \mathrm{ml}$ concentration of leaf extract shows $80 \%$ of non-viability cell. At $200 \mu \mathrm{g} / \mathrm{ml}$ fruit extract shows comparatively less non-viable cells, i.e., $72 \%$ of inhibition of cell was observed at $200 \mu \mathrm{g} / \mathrm{ml}$. Fruit and leaf extracts were showed dose dependent on cytotoxicity on DLA cancer cell lines.
Table 4: Comparison of in vitro cytotoxicity of Zanthoxylum ovalifolium leaf and fruit extracts against EAC cell line

\begin{tabular}{llll}
\hline S. No. & $\begin{array}{l}\text { Drug concentration } \\
(\boldsymbol{\mu g} / \mathbf{m l})\end{array}$ & \multicolumn{2}{l}{ Percentage cell death (EAC) } \\
\cline { 3 - 4 } & & $\begin{array}{l}\text { Leaf } \\
\text { extract }(\%)\end{array}$ & $\begin{array}{l}\text { Fruit } \\
\text { extract }(\%)\end{array}$ \\
\hline 1. & 200 & 82 & 75 \\
2. & 100 & 67 & 66 \\
3. & 50 & 36 & 52 \\
4. & 20 & 22 & 28 \\
5. & 10 & 15 & 20 \\
\hline
\end{tabular}

Control tube contains only one dead cell; the sample dissolves in dimethyl sulfoxide. EAC: Ehrlich ascites carcinoma

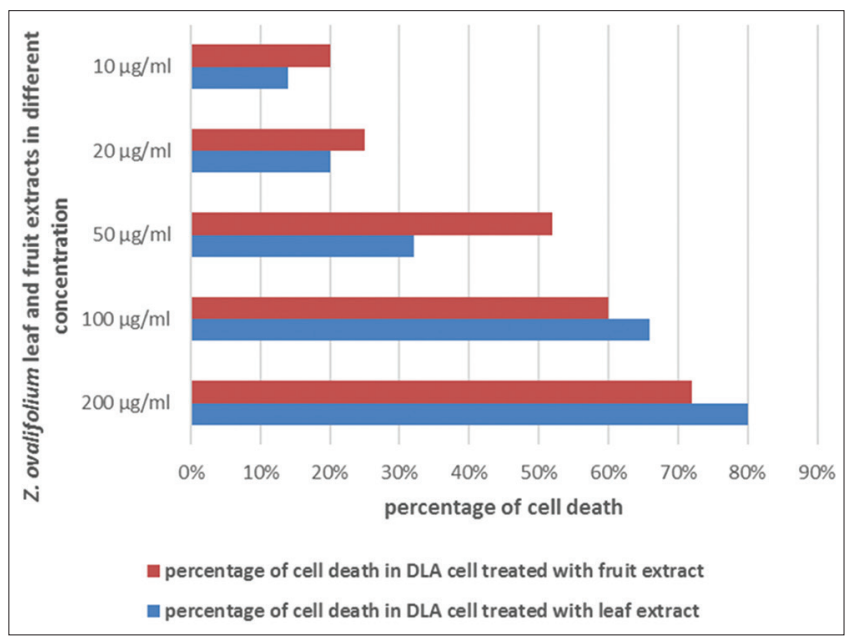

Fig. 1: Percentage of cell viability of methanolic leaf and fruit extract of Zanthoxylum ovalifolium on Dalton's lymphoma ascites cell line

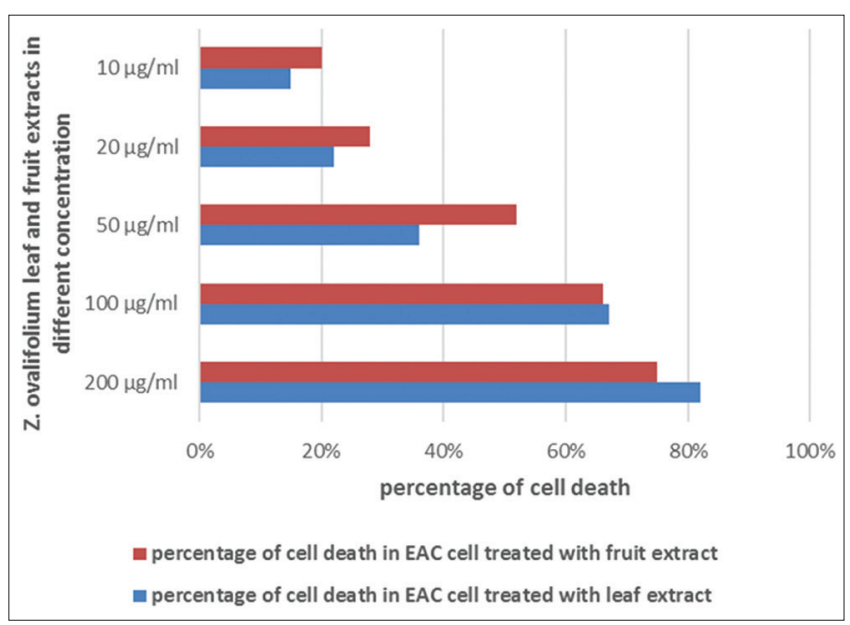

Fig. 2: Percentage of cell viability of methanolic leaf and fruit extract of Zanthoxylum ovalifolium on Ehrlich ascites carcinoma cell line

Similarly, the effect of cytotoxicity on EAC cell line at different concentrations of leaf and fruit extract of $Z$. ovalifolium was ranging from 10 to $200 \mu \mathrm{g} / \mathrm{ml}$ given in Table 4 and Fig. 2 showed dose-dependent inhibition of cytotoxicity. The result shows at initial concentration of leaf extract at $10 \mu \mathrm{g} / \mathrm{ml}$ observed very negligible percentage of EAC cancer cell lines, i.e., $15 \%$ of cell death, whereas $20 \%$ of inhibition was observed in fruit extract. Moreover, the moderate cytotoxicity was recorded in both fruit and leaf extracts at 20, 50, and $100 \mu$ g, i.e., in 
leaf extract observed $22 \%, 36 \%$, and $67 \%$ of EAC cell death and in fruit extract was observed a dose-dependent significant cytotoxic activity $28 \%, 52 \%$, and $66 \%$, respectively.

The cytotoxicity studies on the methanolic leaf and fruit extract of Z. ovalifolium showed promising activity toward tumor cell lines (DLA and EAC) which revealed that both extracts were toxic to the tumor cell which inhibits the growth of cancer cells in a concentration-dependent fashion, but leaf extract showed relatively more effective cytotoxicity against cancer cell when compare with the fruit extract. Fruit extract at $200 \mu \mathrm{g} / \mathrm{ml}$ shows 80 and $82 \%$ significant increase of cell death was recorded for DLA and EAC cell line, and 72 and $75 \%$ inhibition of tumor cell were observed in fruit extract at $200 \mu \mathrm{g} / \mathrm{ml}$ for DLA and EAC cell line. The result of phytochemical screening of $Z$. ovalifolium pronounced the presence of alkaloids and flavonoids in leaf and fruit extract. These biologically active compounds in plant extracts could be an important contributory factor involved in their anticancer potentials. The similar results have been observed on the plants such as Zingiber officinale [17] and Sophora interrupta and the plants from Viscaceae family [18] experimenting in vitro on DLA and EAC cells which can be correlated.

\section{CONCLUSION}

The present study of cytotoxicity activity of both leaf and fruit crude extraction of Zanthoxylum ovalifolium wight. Against DLA and EAC cell line shows significant result of cytotoxic properties, but comparatively leaf extract shows high significant value against then that of fruit extraction Thus, Plant Z. ovalifolium could be exploited as a valuable source of anticancer agent in pharmaceutical industry.

\section{AUTHORS' CONTRIBUTIONS}

Pavani carried out the experiment and wrote the manuscript; meanwhile, Dr. Raja Naika give assistance to the project and conceived the original.

\section{CONFLICTS OF INTEREST}

There are no conflicts of interest.

\section{REFERENCES}

1. Gibbs JB. Mechanism-based target identification and drug discovery in cancer research. Science 2000;287:1969-73.

2. World Health Organization. The Global Burden of Disease: 2004
Update. Geneva: World Health Organization; 2008.

3. Notani P. Global variation in cancer incidence and mortality. Curr Sci 2001;5:18.

4. Bagheri G, Mehdi M, Mehrabi R, Rad J. Cytotoxic and antioxidant activities of Alstonia scholaris, Alstonia venenata and Moringa oleifera plants from India. Jundishapur J Nat Pharm Prod 2016;11:e31129.

5. Newman DJ, Cragg GM, Snader KM. Natural products as sources of new drugs over the period 1981-2002. J Nat Prod 2003;66:1022-37.

6. Subhose V, Srinivas P, Narayana A. Basic principles of pharmaceutical science in Ayurvěda. Bull Indian Inst Hist Med Hyderabad 2005;35:83-92.

7. Moccelini SK, Silva VC, Ndiaye EA, Sousa PT, Vieira PC. Phytochemical study from root barks of Zanthoxylum rigidum Humb. and Bonpl. ex Willd (Rutaceae). Quim Nova 2009;32:131-3.

8. Facundo VA, Silveira AS, Filho RB, Pinto AC, Rezende CM. Chemical constituents of Zanthoxylum ekmanii (URB.) Alain. Quim Nova 2005;28:224-5.

9. Silva FB, Santos NO, Pascon RC, Vallim MA, Figueiredo CR, Martins RC, et al. Chemical composition and in vitro cytotoxic and antimicrobial activities of the essential oil from leaves of Zanthoxylum monogynum St. Hill (Rutaceae). Medicines (Basel) 2017;4:e31.

10. Mukhija M, Singh MP, Dhar KL, Kalia AN. Cytotoxic and antioxidant activity of Zanthoxylum alatum stem bark and its flavonoid constituents. J Pharmacogn Phytochem 2015;4:86-92.

11. Epifano F, Curini M, Marcotullio MC, Genovese S. Searching for novel cancer chemopreventive plants and their products: The genus Zanthoxylum. Curr Drug Targets 2011;12:1895-902.

12. Talwar GP. Handbook of Practical Immunology. New Delhi: National Book Trust; 1974. p. 336-9.

13. Sandberg F, Corrigan D. Natural Remedies. Their Origins and Uses. Abingdon: Taylor and Francis; 2001.

14. Ashwathanarayana R, Naika R. Antioxidant and cytotoxic properties of Pavetta crassicaulis Bremek. leaf crude extract and its isolated pure compound. Indian J Nat Prod Resour 2017;8:335-50.

15. Ashwathanarayana R, Naika R. Study on antioxidant and cytotoxic properties of Olea dioica Roxb. crude extract and its pure compound collected from Western Ghats, Karnataka, India. Asian J Pharm Clin Res 2017;10:56-67.

16. Jeena K, Liju VB, Kuttan R. Antitumor and cytotoxic activity of ginger essential oil (Zingiber officinale Roscoe). Int J Pharm Pharm Sci 2015;7:342-4

17. Mathi P, Nikhil K, Das S, Roy P, Bokka VR, Botlagunta M. Evaluation of in vitro anticancer activity and gc-ms analysis from leaf Sophora interrupta Bedd. Int J Pharm Pharm Sci 2015;7:303-8.

18. Kuttan R, Shivamurthy GR, Kuttan G. Potential anti-tumor and antiinflammatory activity of six mistletoe plants in the family viscaceae present in Western Ghats, India. Int J Pharm Pharm Sci 2017;9:57-64. 